\title{
Motivating Factors of Community Engagement Practices among Nigerian Professors
}

\author{
Samuel Olutokunbo Adekalu, Suandi Turiman, Steve Eric Krauss, Ismi Arif Ismail \\ Department of Professional Development and Continuing Education, \\ Faculty of Educational Studies, Universiti Putra Malaysia, Selangor, Malaysia \\ Corresponding Author e-mail: adekaluolutokunbo@gmail.comTel. No: +601-6966-4362
}

\begin{abstract}
This study explored the reasons for Nigerian university professors participating in community engagement activities and examined factors that influence their participation. The subjects used in this study were from the Kwara State University, Malete, Nigeria. Utilizing qualitative method with indepth interviews with (9) nine professors who had between 15 to 40 years working experience in the academia. From the analysis, four main motivating factors were found to contribute to the university professors' participation in community engagement activities. These were: (a) organizational structure and incentives; (b) upbringing and orientation; (c) desire to change and impact people's live; and (d) personal satisfaction. Implications of these findings call for theory and practice and directions for further research of the process of community engagement practice among academics.
\end{abstract}

Keywords: Community Engagement, Motivation, University Professors, Nigeria.

\section{Introduction}

Ryan \&Deci (2000) described being motivated as being moved to do something, implying that when a person is not moved or inspired to do something, such person is said to be unmotivated. They further explained motivation by stating that being motivated means that a person is activated towards an end. According to these scholars individuals have different kinds and amounts of motivation. The factors that motivate most of the academics involvement in community engagement are well researched and documented in the extant literature (Abes, Jackson \& Jones, 2002; O'Meara, 2004; Jaeger \& Thornton, 2005; Colbeck\& Michael, 2006; Adekalu, Krauss, Turiman\& Ismail, 2017). Findings of such research have shown that the academics are motivated by certain factors to be involved in community engagement. In this study, the factors reviewed are classified into two categories, extrinsic and intrinsic.

In this study, community engagement represents the numerous ways in which academics engage with communities, together with research and teaching to promote economic, environmental and sociocultural development. According to Driscoll (2009), the term community engagement is refers to as the collaboration between higher education institutions and their larger communities. Community engagement process entails the creation, integration, application and transmission of knowledge for the benefit of external audience and the university (Sandmann, 2007). Austin \&Gamson (1983) who carried out an all-inclusive literature review on faculty and factors that affect faculty work, found different factors which they grouped into two major categories; extrinsic and intrinsic. Extrinsic factors are those factors that relate to the environment and working conditions such as workload, reward systems, policies and opportunity structures. On the other hand, intrinsic factors focused on the nature of the work and the impact it has on faculty members, how the work is carried out, and the series of activities associated with the work as well as the amount of feedback which an individual gets about engagements. 
Community engagement is a challenging task for academics to perform due to the work-related responsibilities; they have to teach, supervise students, advice students and carry out other professional duties (Boyle \& Sawyer 2010; Terosky, O’Meara \& Campbell, 2014; Ziker, 2014; Adekalu et al., 2017). One of the reasons why it is also difficult for most academic to be involved in community engagement is because it is often regarded as "service," which has little value in the academic reward system (Vogelgesang, Denson \&Jayakumar, 2010). Community engagement is viewed as an impediment to promotion because it is time consuming and does not allow those who participate in it to do other meaningful work (Weerts\&Sandmann, 2010). Pursing community engagement at the expense of career advancement is unreasonable if it is not aligned with promotion requirements and tenure at institutional level. In other words, if community engagement cannot be rewarded as a requirement for promotion, then it is unwise to engage in such activities (Gorski\&Metha, 2015).

Past studies revealed that institutional factors such as university policies on community engagement, financial and moral support (encouragement and provision of facilitative environments) motivate community engagement of academics. As observed by Stanton (1991), a more facilitative environment is provided by institutions for community engagement through adequate support for curricula that is problem-oriented, interdisciplinary and applied. However, it becomes difficult for professors to be involved in community development if their institutions views community engagement as an activity that is independent of research and teaching (O'Meara, 2002). The challenge in engaging in community work in a university that does not harmonise community engagement with teaching and research, lies in the fact that academics have less time with more tasks to perform (Rice, Sorcinelli\& Austin, 2000), and when they engage in community work they have to compete for external resources. This can deter them from involving in community engagement because it takes extra time.

In the existing literature on community engagement, institutional policy and mission has been highlighted as a motivating factor which motivates academics to be involved in community engagement. This means that some academics only engage because it is the policy or mission of their institution, and not because they are interested in doing so. For example, O'Meara (2008) found that $50 \%$ of the files which she examined for her study showed that the study participants were motivated to engage in community work because it is required by the institution that faculty members must engage in one or more community works to be promoted on the job. According to Colbeck\& Weaver (2008), members of university are motivated to engage in community work if the university makes it part of its policy to support community engagement. In their study which was carried out at the Pennsylvania State University, they found that a group of administrators and faculty members were dedicated to integrating research, teaching and the service aspect of their work for community development.

Apart from extrinsic motivation, intrinsic motivation in humans is an important and pervasive kind of motivation which is a natural motivational tendency. According to Ryan and Deci (2000), knowledge and skills are developed through intrinsic motivation which drives individuals to act or engage in certain behaviours through natural interest or because of the satisfaction derived from engaging in such behaviour. This means that individuals, who act based on intrinsic motivation, do not need extraneous incentives to do so, because they are natural ready to explore and engage in an activity. Austin \&Gamson (1983) cited in O'Meara (2008) identified two perspectives of intrinsic motivation; motivations exist within individuals and it also exists between individuals and activities. Scholars who defined intrinsic motivation did so based the activity being interesting to an individual (e.g., Deci, 1975; Deci\& Ryan, 1985, 1991), while others based it on the satisfaction which the activity gives a person (e.g., Hammond, 1994; Blackburn \& Lawrence, 1995). In the continuum of community engagement of university academics, intrinsic motivation may include, personal 
satisfaction, achievement of personal goals (improving student learning, achievement of career goals) and personal commitments to certain social issues (Neumann, 2000; O’Meara, 2008).

Academics have personal goal associated with community engagement activities which is not limited to the desire to improve student learning. Neumann (2000) noted that improving student learning is an intrinsic motivation which drives academics to be involved in community engagement. It has been suggested by research (Hammond 1994; Abes, Jackson \& Jones 2002; McKay \&Rozee, 2004; Terosky, 2005) that the reason why academics are motivated to become engaged in community work is because they believe it can enhance student learning; students are able to have better understanding of course content, thereby enhancing student development. On the other hand, findings of previous studies have shown that academics feel unmotivated to engage in community work if they perceive that it will not help them achieve teaching goals.

More so,previous studies have shown that some university academics get involved in community engagement because they strongly believe that it is a cutting-edge for their area of specialization as well as for professional communities that are external to their institutions (O'Meara 2002; Boyte 2004; Adekalu et al., 2017). They also involve in community engagement because they believe that through their engagement in consultancy and volunteer work outside the university settings, they can get to the peak of their career in their area of specialization. Similarly, findings of a study carried out by Boyte (1999) among faculty exemplars revealed that they did viewed community engagement as fountain of intellectual expansion, rather than a secondary type of research. These studies found that through community engagement, faculty members were able to apply their theoretical knowledge in solving practical problems of communities.

In addition to other intrinsic motivations, some academics have expressed that they are motivated to engage in community work because of the satisfaction they derive from it (Blackburn \& Lawrence, 1995; Neumann, 2000). This is a typical intrinsic motivation which drives individuals to engage in an activity because of the satisfaction it gives them. Janke\&Colbeck (2008) found that academics were motivated to engage in community work because of the satisfaction they derived from seeing the positive impacts of their community engagement on the community and their students as well. Janke\&Colbeck (2008) concluded that university academics may be more motivated to be involved in community engagement if they have the opportunity to see how their engagement helps in changing the situations of community or the learning process of students. This means that seeing tangible outcomes may motivate academics to continue engaging in community work.

Further, personal commitment to specific social issues, certain people or event, has also been found to be a motivating factor for some academics to engage in community work (Neumann, 2000; O'Meara, 2008). Some academics engage in community work because of the passions they have for some specific places, people or social issues. For example, a study conducted by Boyte(2004) revealed that many academics were motivated to engage in community work by their personal commitments to specific issues or issues of social justice. It was also found by Pollack (1999) that early pioneers of community engagement were motivated by passion to use education in serving the society, a desire for social justice and a desire to be engaged in democratic education. University professors are an interesting population to study since understanding the motivations for their community work is paramount to engagement and its sustainability. Therefore, the current study focused on understanding the reasons why university professors are involved in community engagement. 


\section{The Current Study}

Past studies have revealed that academics involvements in community engagement in Nigerian universities are not embraced, and little attention is given to it (Yusuf, Adebowale, Fagbamigbe, Bamgboye\&Oyediran, 2010; Ifedili\&Ifedili, 2015; Adekalu, Shuti, Turiman, Olohungbebe\&Adio, 2017). However, there are few universities that have given priority to community engagement because they understand its contribution to the growth and development of communities, the universities, students and academics. An understanding of this will help institutions of higher learning; especially universities understand the reasons why academics involve in community engagement so that they can play their own role in facilitating community development through institutional engagement. This study was carried out in one of the few universities that have embraced and is practicing community engagement. A review of the literature on factors that motivate university academics to be involved in community engagement shows that there are different motivations that attract academics towards community engagement and sustains them as well. Existing findings of previous studies are crucial to conceptualizing the various types of motivations that university academics experience. However, findings of past studies must be complemented with new researches in order to discover new motivations that are not found in the extant literature. Thus, this study explored the motivating factors of community engagement activities among teaching professors in Kwara State University, Nigeria.

\section{Methodology}

This study adopted qualitative approaches to include the data from participant observations, case study, and in-depth semi structure interviews (Das, 1983). The qualitative data consist of interview transcripts, observations from the researchers, detailed descriptions from case studies, field notes, and documents and academic and professional journal publications (Patton, 2002). Purposive sampling method was used in selecting nine university professors involved in community engagement. Kwara State University, Nigeria which is the institution in which the professors' work was also selected using purposive sampling technique. This technique allows the researchers to choose specific samples that provide insights into the issues related to the study area (Alston and Bowles 2003).

In carrying out this study case, nine university professors were used. Merriam (2014) maintain that the small sample size will enable authors to have in-depth understanding of the research phenomenon and not seek for statistical generalization. In the current study, the same criteria were used for selection of the study participants; they have to be university full professors, they must have University/College Bachelor degree, have University/College Master degree, have Doctor of Philosophy (PhD) or equivalent degrees from local or foreign government approved or recognized institutions, have had at least fifteen years of career work experience in the academia, have had at least sufficient experience and regular engagement in community service, must have had received recognitions and awards within and outside of the university for community engagement activities in related field of study and acknowledged by the university authority. The study data were obtained at the Kwara State University, Malete, being an institution with the philosophy of community development. The university was approved as a "University for Community Development" by Kwara State Government with a reputation for excellence in teaching, research and community interventions.

The nine professors for this study were from nine different academic backgrounds and departments at the Kwara State University. The participants were selected from within the College of Agriculture, Applied Sciences, Education, Engineering, Humanity, Information Communication Technology, and Social Sciences. Among the nine participants, seven were males and two were females. The age of the participants ranged from early 40s to early 70 s, the average age being in the late 50 s. They all had more than 15 years of work experience in academia. Within the sample, three of the professor had 
their doctoral degrees in Nigeria, while the remaining six had their Doctoral degrees from overseas institutions, namely the United States, United Kingdom, Netherlands, France, and Canada. They were all Nigerian nationals.

Each participant was interviewed between 1 to 4 times in throughout the study. Each interview lasted approximately 20 minutes to 2 hours. A total of nineteen (19) one-on-one interviews were conducted. Documentary review was carried out during fieldwork when no interviews were been carried out. The documents were reviewed to support the data collected through interviews, participant observation, memos and field notes. The table (1) below shows the details of the professors who participated in the research:

Table 1: Research Participants, College, Area of Expertise and Gender

\begin{tabular}{|c|c|c|c|}
\hline Participants & College & Area of Expertise & Gender \\
\hline PK1 & Agriculture & Plant bridging and Genetic & Male \\
\hline PK2 & Education & Sport Management & Male \\
\hline PK3 & Agriculture & Agricultural Extension & Male \\
\hline PK4 & Engineering & Soil and Water & Male \\
\hline PK5 & Humanity & Gender and English Literature & Female \\
\hline PK6 & Humanity & Linguistics & Female \\
\hline PK7 & Applied Science & Geology & Male \\
\hline PK8 & Social Science & Political Science & Male \\
\hline PK9 & ICT & Computer Science & Male \\
\hline
\end{tabular}

\section{Results}

The different responses given by the participants showed that the participants have different factors that motivate their participation in community engagement. Four major themes emerged from the different categories extracted from the interviews with participants. In order to derive the four major themes, the categories which emerged were critically examined in order to find out similarities between the different categories; related categories were merged to form major themes. The themes are; upbringing and orientation, desire to change and impact lives, personal satisfaction and organizational structure and incentives.

\section{Organizational Structure and Incentives}

Majority of the participants of this study revealed through the interview that one of the factors that motivated them to participate in community engagement is the University's policy regarding community engagement. One of the participants said the mission of the university which is community service inspired him to participate in community engagement. He stated that despite the fact that other universities claim to focus community engagement, they do not implement it in practice. Participant PK1 noted that: 
"You know when you say you work in the university there are 3 things that must be emphasised; teaching, research and community development. I see KWASU as in fact the only university that emphasizes the idea of community development. In most universities, this is silent, but in KWASU this is the focus".

This participant further explained that KWASU has made it mandatory for them to relate their research to their immediate community in the sense that their research must have an impact on the community.

Participant PK2 also expressed similar view to that of Participant N1 in regards to community engagement being part of the mission and vision of KWASU. Participant PK2 stated that: Community development is part of the mission and vision of KWASU and therefore it has become part and parcel of the university because on a yearly and quarterly basis, it engages in community outreach activities.

While the university mission and vision is the motivation for some of the participants, some of the participants expressed that they are motivated to participate in community development by the university policy which makes participation in community development a criterion for promotion. Some of the participants expressed that $20 \%$ is given to engagement in community development during promotion. They explained that even though the university considers research publications as a criterion for promotion, this alone cannot earn one promotion except it is combined with engagement in community development activities. One of the participants stated that:

"Just like any other university in the world, community development in $K W A S U$ is a criterion for promotion. Here in KWASU the university emphasises on community development and so therefore, if you don't score up to 3 points in community development then you don't get promoted. More so, the university will ask what has one done for the community in the last 2-3 years while waiting for promotion, what has one done with his/her expertise/knowledge. Not meeting this criterion in KWASU will result in no promotion".

Participant PK6 also expressed that the policy of the university which made participation in community development activities a criterion for promotion inspired him to participate in community development activities as he noted that:

"Faculty members engage in community development because they know it is part of the criteria for promotion. So, I tell my staffs, for promotions remember you have to engage in community service. So go out and reach out so that you can be promoted. Even though, publication is part of the criteria for promotion, community service is also emphasised".

However, the position of the participants shows that university policy on community engagement is one of the factors that motivate university professors to participate in community development activities. The former involves motivation gotten from environment and surrounding condition such as reward system, working conditions, opportunity structure and policies while the latter is about the nature of an engagement itself, how it is done how individuals that participate in the engagement are affected. In the context of this study it can be said that the Professors are motivated by the policy of the university on community development which is an extrinsic factor. 


\section{Orientation and Upbringing}

Apart from the policy of the university on engagement in community service, personal orientation was found to be one of the factors that motivated university professors to participate in community service. While some participants explained that their previous educational background motivated their participation, other expressed that their family upbringing motivated their participation in community service. Some participants indicated that before they began their career in education in KWASU they had previously participated in community service during school days as part of their training. This motivated their participation in community service in KWASU. More so, some of the participants revealed that their upbringing served as a motivation for them to participate in community engagement. They explained that while they were growing up, they understood that it is important to help. Therefore, family up-bringing helped them to see the importance of helping to solve the problems of their community. One of the participants stated that:

"I want to say that my up-bringing and religion have been a source of inspiration for me to really get involved in community development; I have rendered service to many people just like my father whom in his time preferred to train other people by investing huge sum of money for their training. He usually helped people in the community whom he knew were not financially buoyant to train their children. We used to complain then but this act of his gave us a reason to engage in community development when we all grew up".

This participant PK2 further explained that his religion is one of the factors that motivate his participation in community service as he stated that: "Well, this is a normal thing in the scripture; it is in all the books, in the Quran, Bible and even in traditional practices. Helping people solve their problems is also a religious thing".

Participant PK3 expressed that his educational background is what inspired him to participate in community service. In the interview he explained that starting from his early years in university as an undergraduate student he engaged in community development as an extension researcher. This participant said that he has been into community development for 35-36 years and have been solving the problems of community through his research. The interview indicated that Participant PK3 majorly engages in community service which is related to his area of specialization which is agricultural development as noted that:

"I have been engaged in this community development for the past 35-36 years since I joint the university during my undergraduate days till now. When I finished by B.Sc. programme in agriculture in Philippines, I joined the National Research Institute as an extension researcher and my duty at that time was to go to the farmers across the country because the research institute had a mandate for rice production. As the extension researcher I visited different communities and took research data on their problems and their needs and reported back to the research stations so that researchers could work on them. Afterwards, solutions are found and taken back to the farmers. So I will say my undergraduate education is what first motivated me to engage in community service before I came to KWASU".

Participant PK4 had similar experience with Participant PK3 who started engaging in community development since university days. He said that he began engaging in community development when he was studying Sweden where he was exposed to community problems which he was meant to solve by using what he was thought in class. He said that: 
"In one way or the other I have been involved in community development even as a student when I was schooling in Sweden. I involved in some projects in different communities; I helped in solving problems related to soil erosion because I was studying Geography. However, my interest for community development increased when I changed my specialization from geography to agricultural engineering in Calgary Canada where I did my Masters. During my undergraduate days in Sweden I was exposed to different kinds of community problems and some of them were erosion and shortage of water. So from there I was able to understand that the need of the community was irrigation which was costly and because I had studied how to manage water scarcity during my degree final year so I helped to solve this problem by introducing rain harvesting to the community. This helped in solving the problem. So like I said earlier, my early experience in community development is one of the things that have motivated me to engage in community service".

This finding indicates that the educational and family backgrounds of the participants are part of the factors that motivate the participation of KWASU Professors in community service aimed at developing the community.

\title{
Desire to make Change and Impact People's Lives
}

Based on the interviews conducted with the subjects of this study, some of the Professors of KWASU are also motivated by the strong desire to impact the lives of people in the community through research. It was also found that they were motivated by the desire to share their knowledge with the people of the community who had little or no information on things that could solve some of the problems they faced. The Professors explained that having knowledge that cannot be used to change the lives of the people in the community is as good as nothing. They further disclosed that whatever kind of research they conduct they try to link it to the community by ensuring that the outcome of such research will solve a problem of the community as one of the participants stated:

\begin{abstract}
"I will always say that "charity begins at home", that is, you cannot say you love anybody or you love somebody that is far away unless you love the people around you. Also you cannot say you want to make an impact on the world, you first make an impact in your immediate environment. KWASU has made it clear to us that our research must impact the community. When I came to KWASU I was made to understand that the community is the focal point of our research. What I am trying to say is that the community has become the focal point of our research and our thinking. So, it's very interesting to realize that. It is good to know that you are imparting on the society positively".
\end{abstract}

Participants PK6 further explained that she is motivated to engage in community development because she loves helping people especially young people because she feels that they deserve to have better lives. This respondent said that this desire to impact the lives of young people is what motivates her to engage in community development so that she can share new ideas and knowledge with the youths as she stated that: I like helping young people because they deserve it just like other countries like to take care of their children. When you see something better, you will also want it for your own; this is why I really am really concerned and want to help.

She also explained that even though Professors are being paid for lecturing students, she see it as a way of imparting knowledge in the youths which will in turn develop the present generation and down to the next generation as she noted: 
"I see my teaching as a kind of community development because we are teaching young people and every day when am in class, I mean the class room...... just want to offer them new ideas, knowledge and so forth. So I will say all teachers engage in community development even though we are being paid for it, but we need to look beyond the pay and see this as a service that we are rendering our people. So we have to pay back by imparting knowledge in the next generation; I see it as a privilege".

\section{Personal Satisfaction}

While other respondents expressed that they were motivated to engage in community by their family and educational background, passion to impact and university's policy on community engagement, some other respondents expressed that they were motivated by the personal satisfaction which they derived from engaging in community development. One of the respondents expressed that he engages in community development because he derives satisfaction from doing so. He explained that even though money is involved, money cannot be quantified with the exchange of knowledge which he engages in each time he participates in community development. He stated that:

"I told you that....erm for me, I cannot quantify money and I can't exchange money for sharing knowledge. For instance, I was sitting down some weeks ago and I received a call from a Professor at Babcock University saying he would like me to be an external examiner to his 2 Ph.D students who had already submitted their thesis. I know money is involved but for me it is not mainly because of the money but I got involved because of the satisfaction".

Another participant also explained that it gladdens his heart to know that he has contributed his own quota to the development of the community through knowledge-sharing as he noted that:
"Well, you know I feel just happy and satisfied to have contributed to that, the knowledge that organic manure can easily replace the inorganic. The organic is readily available, but the idea that they can use it to get what they want gladdens my heart and to know that they can also it in effective manner; this is something I am also happy about".

In the same vein of satisfaction derived from community development, Participant PK4 further explained that:

"Living in an environment where everyone is miserable makes one sad and unable to work well. I mean I don't derive any pleasure in finding people who are hungry. If I have, I can make sacrifice for others. Sometimes even than you, you will not get from people, but I can tell you that more than anything else the little thank you one gets from minority is enough to make you feel good. Personally, I will say that I have been lucky to live in an environment where I have more friends than enemies, where people appreciate more than those who do not. The most exciting and motivating thing to me is the feeling of satisfaction that people around me are happy; I have more happy than unhappy people around me".

\section{Discussion}

The findings revealed the reasons why Nigerian professors participate in community engagement. The Professors indicated that they were extrinsically and intrinsically motivated to participate in community engagement (Ryan \&Deci, 2000). The factors that motivate university academics to be 
involved in community engagement are well researched and documented in the extant literature (Abes, Jackson \& Jones, 2002; O’Meara, 2004; Jaeger \& Thornton, 2005; Colbeck\& Michael, 2006). Research findings have shown that university academics are motivated to involve in community engagement by some factors. In this study, the factors found are classified into two categories, extrinsic and intrinsic. This finding supports the results of Austin \&Gamson (1983) cited in O'Meara (2008) who through a comprehensive review of literature found that individuals can be motivated extrinsically and intrinsically. The former involves motivation gotten from environment and surrounding condition such as reward system, working conditions, opportunity structure and policies while the latter is about the nature of an engagement itself, how it is done how individuals that participate in the engagement are affected. In the context of this study it can be said that the Professors are motivated by the policy of the university on community engagement which is an extrinsic factor. Austin \&Gamson (1983) explained that individuals may not be motivated to participate in an activity, but policy may be a driving force for engagement. This researcher also stated that incentives could be a driving force for community engagement which in the case of this study is the $20 \%$ given to community engagement during promotion. The participants did mention that this greatly motivates them to engage in community development.

This finding also supports the results of O'Meara (2008), who also conducted an exploratory study explored the motivations of sixty-eight exemplars in community engagement and found that the exemplars were motivated by institutional mission and policy on community engagement. Thus, it can be said that the university understands the importance of community engagement in national development that is why it has made community engagement part of its mission as well as incorporated community engagement into its promotion policy by making it a criterion for promotion.

More so, findings of past studies have shown that academics are motivated by past experiences at home or school. O'Meara (2008) also found that the community engagement of faculty members was driven by past experiences of the faculty members. These experiences were encountered either in the home or at school as some of the participants of the study expressed that the engaged in community development because while they were growing up they learnt in their homes through their parents who also engaged in community development services that responsible people take "thoughtful and caring action to bring about changes in the world" (O'Meara 2008, p18). Other researchers have also found similar motivation for community engagement (Eisenberg \&Fabes, 1998; Fletcher, Elder, \&Mekos, 2000; Rehberg, 2005; Gran, 2006; Adekalu et al., 2017).

The finding of this study which indicates that the teaching received by the professors from their family when growing up motivates them supportsBanovcinova, Kovalcikova\&Hrdlickova (2014) study. In their study they investigated how the acquisition of rules, values and roles are influenced by individual characteristics of family. Their findings showed that through the family which an important agent of socialization, individuals is are able to acquire basic principles and rules of functioning in the society.

The current study also revealed that academics are motivated to engage in community work by their personal commitments to specific social issues. Findings of previous studies have obtained similar results showing that individuals can be motivated by personal commitments to certain issues in the society; this makes them to engage in community development so that they can solve problems faced by the community (Blackburn \& Lawrence 1995; Neumann 2000). It was also found that the participants were motivated by the desire to share their knowledge with the people of the community who had little or no information on things that could solve some of the problems they faced. The Professors explained that having knowledge that cannot be used to change the lives of the people in the community is as good as nothing. So therefore they chose to use their knowledge to conduct 
community-based research that can at the end solve the problems of the community. This view of the participants supports current literature which describes community engagement as the use of professional knowledge and expertise to solve real-world problems in a manner that fulfils the mission of the institution (Elman \& Smock 1985; Boyer 1990; Lynton 1995; Bloomfield 2006).

Therefore, it can be said that personal commitment which is characterised by the desire to impact the lives of people is a motivating factor for community engagement because a study conducted by Gallup (2004) has also shown that most volunteers engage in community development service because they want to do something which others can benefit from. This form of motivation is in the literature of volunteerism and motivation is referred to as altruistic motivational factor. Altruism is defined by Tooby\&Cosmides (1996) as any kind of action taken in the interest of other people, some times at the detriment of the benefactor and sometimes not.

It was also found in this study that personal satisfaction and the feeling of fulfilment which professors get from engaging in community service motivates them to engage, even without receiving any incentive (Widjala, 2010). Dolnicar\& Randle (2007) noted that individuals who voluntarily engage in community service most times do so, for the personal satisfaction they derive from the engagement knowing that they are making worthy contributions to community development. Brudney (2005) also found that individuals engage in community service for the mere satisfaction derived from knowing they are offering something to the society which in turn gives them a feeling of achievement. This kind of motivation can be described as intrinsic motivation which is noted by Blackburn \& Lawrence (1995) as the motivation to engage in something because of the personal benefit derived from the engagement; in relation to this finding, personal satisfaction is the benefit which Professors enjoy when they engage in community development.

\section{Conclusions, Recommendations and Directions for future Research}

The current study explored the reasons why Nigerian professors participate in community engagement activities. There were four major reasons found in this study; orientation of Professors, desire to change lives and impact the community, personal satisfaction derived from participation and organizational structure and incentives. Despite the fact that this study was only carried out in one Nigerian public university, the findings of this study may be relevant to other educational institutions that share the similar characteristics with the university in which the present study was conducted. These findings may help such institutions understand the reasons why academics engage in community work, thereby being able to enhance the engagement of its staff. Understanding these motivations can help in promoting better engagement among academics and other individuals that want to participate in community engagement. Findings of the study revealed that institutions of higher education can motivate their academics to engage in community development is by developing policies that support community engagement. The findings help in countering the assumption that the lack of engagement of professors is due to their work-related responsibilities (Terosky, O'Meara \& Campbell, 2014; Ziker, 2014; Adekalu et al., 2017), because it has revealed that there are other factors that play an important role in the community engagement of Professors.

Just like any other study, this study is not without limitations. The study is limited by the scope, research design used and the study sample. Therefore, future study can further examine the factors that influence academics at different levels within institutions of higher learning to engage in community work quantitatively. A quantitative approach may help in enhance the transferability of findings because of the sample size that will be used. More so, the use of a quantitative approach may reveal more factors. 


\section{Acknowledgment}

This work was supported by Petroleum Technology Development Fund (PTDF) Nigeria, with reference number PTDF/E/OSS/PHD/ASO/616/14.

\section{References}

Abes, E., Jackson, G. \& Jones, S. (2002). Factors that motivate and deter faculty use of servicelearning.Michigan Journal of Community Service Learning 9 (1): 5-17.

Adekalu, S. O., Krauss, S. E., Turiman, S. \& Ismail, I. A. (2017).Exploring the Personal Philosophies of Volunteerism among Professors at a Malaysian Research University.OUSL Journal,12(1): 91-108.

Adekalu, S. O., Shitu, M. B., Turiman, S., Olohungbebe, L. O. \&Adio, A. A. (2017).Facilitating Community Development through Institutional Engagements: Reflections from 2016 Nigeria IACD Conference.Journal of Resources Development and Management, 30, 132-140

Alston, M. \& Bowles, W. (2003). Research for social workers: an introduction to methods 2nd edn, Allen \&Unwin, NSW, Australia

Austin, A. \&Gamson, Z. (1983). Academic workplace: New demands, heightened tensions. ASHEERIC Higher Education Research Report, no. 10. Washington, DC: George Washington University.

Bandura, A. (1977). Self-efficacy: Toward a unifying theory of behavioral change. Psychological Review 84 (2): 191-215.

Banovcinova, A., Kovalcikova, N. \&Hrdlickova, D. (2014). An important area of socialization in the family is also the acquisition of basic rules and standards of functioning in society. International Multidisciplinary Scientific Conference on Social Sciences and Arts SGEM2014, Conference Proceedings, September 1-9, 2014, Book 1, Vol. 2, 409-416

Blackburn, R. T. \& Lawrence, J. H. (1995). Faculty at work: Motivation, expectation, satisfaction. Baltimore, MD: Johns Hopkins University Press.

Bloomfield, V. 2006.Civic engagement and graduate education.Communicator 38 (3): 1-2, 6. Washington, DC: Council of Graduate Schools.

Boyer, L. (1990). Scholarship reconsidered. Priorities of the Professoriate, Special Report, New York: The Carnegie Foundation for the Advancement of Teaching.

Boyte, H. C. (2004). Going public: Academics and public life. Dayton, OH: Kettering Foundation.

Brudney, J.L. (2005). Designing and managing volunteer programs. In Robert D. Herman (ed.) TheJossey-Bass Handbook of Nonprofit Leadership and Management.Second Edition. San Francisco: Jossey-Bass, 310-344.

Colbeck, C. \& P. Michael (2006). Individual and organizational influences on faculty members' engagement in public scholarship.In Public scholarship, ed. R. A. Eberly and J. R. Cohen, 1726.New Directions for Teaching and Learning. San Francisco, CA: Jossey-Bass. 
Colbeck, C. L. \& Weaver, L. D. (2008).Faculty Engagement in Public Scholarship: A Motivation Systems Theory Perspective. Journal of Higher Education Outreach and Engagement, 12, (2), 7-32

Das, T. H. (1983). Qualitative research in organizational behavior.Journal of Management Studies, 20(3), 301-314.

Deci, E. L. (1975). Intrinsic Motivation. New york: Plenum Press.

Deci, E. L. \& Ryan, R. M. (1985).Intrinsic Motivation and Self-determination in human behaviour. New York. Plenum Press.

Deci, E. L. \& Ryan, R. M. (1991). A motivational approach to self: Integration in Personality. In R. Dienstbier (Ed.), Nebraska Symposium on motivation: Vo;. 38. Perspectives on motivation (pp. 237-288) Lincoln, NE: University of Nebraska Press.

Dolnicar, S. and Randle, M. (2007). What motivates which volunteers? Psychographic heterogeneity among Volunteers in Australia.Voluntas: International Journal of Voluntary and Nonprofit Organizations, 18(2), 135-155.

Eisenberg, N. \&Fabes, R. A. (1998).Prosocial Development.In Damon, W. \& Eisenberg, N. Handbook of Child Psychology eds. 5th ed. Social, emotional and personality development, no. (3), 701-778. New York: Wiley and Sons.

Elman, S. E. \& S. M. Smock (1985).Professional service and faculty rewards: Toward an integrated structure. Washington, DC: National Association of State Universities and Land-Grant Colleges.

Fletcher, A. C., Elder G. H. \&Mekos, D. (2000). Parental influences on adolescent involvement in community activities. Journal of Research on Adolescence, no. (10), 29-48.

Gran, B. (2006). Public-private obstacles to voluntary service and citizenship. In Williamson, H., Hoskins, B. \&Boetzelen, P. Charting the landscape of European youth voluntary activities, eds. 121-133. Strasburg, France: Council of Europe.

Gorski, I. \&Metha, K. (2016).Engaging Faculty across the Community Engagement Continuum.Journal of Public Scholarship in Higher Education, (6), 108-123

Hammond, C. (1994). Integrating service and academic study: Faculty motivation and satisfaction in Michigan higher education.Michigan Journal of Community Service Learning 1 (1): 21-28.

Ifedili, C. J. and Ifedili, C. (2015). Management of Nigerian Universities and Community Services, European Journal of Business and Social Science, 4(9): 14-21.

Jaeger, A. \& Thornton, C. (2005). Neither honor nor compensation: Faculty and public service. Paper presented at the Association for the Study of Higher Education annual meeting, Philadelphia, PA, November 18.

Janke, E. M \&Colbeck, C. L (2008).An Exploration of the Influence of Public Scholarship on Faculty Work.Journal of Higher Education Outreach and Engagement, 12(1), 31-44.

Lynton, E. (1995). Making the case for professional service. Washington, DC: American Association for Higher Education. 
Merriam, S. B. (2014). Qualitative Research: A Guide to Design and Implementation. John Wiley \& Sons.

McKay, V. C., and Rozee, P.D. (2004).Characteristics of faculty who adopt community servicelearning pedagogy.Michigan Journal of Community Service-Learning 10 (2): 21-33.

Neumann, A. (2000). Toward a profession of learning: Exploring how university professors learn through their subjects through teaching. Paper presented at the meeting of the American Educational Research Association, New Orleans, LA, April.

O’Meara, K. (2004).Motivation for Faculty Community Engagement.Journal of Higher Education Outreach and Engagement, Volume 12, (1), 7-29

O’Meara, K. (2008). Motivation for faculty community engagement: Learning from exemplars. Journal of Higher Education Outreach and Engagement, 12(1), 7-29

O’Meara, K. (2002). Uncovering the values in faculty evaluation of service as scholarship.Review of Higher Education (Summer): 57-80.

Patton, M. (2002).Qualitative Research \& Evaluation Methods. Thousand Oaks, CA: Sage Publications.

Pollack, S. (1999). Early connections between service and education. In Service-learning: $A$ movement's pioneers reflect on its originsfuture, ed. Timothy K. Stanton, Dwight Giles, and Nadinne Cruz, 12-32. San Francisco: Jossey-Bass.

Rice, E., Sorcinelli, M.D., Austin, A. (2000). Heeding newvoices: Academic careers for a new generation, New Pathways: Faculty Careers and Employment for the $21^{\text {st }}$ Century, Inquiry \#7. Washington, D.C: AmericanAssociation for Higher Education.

Stanton, T. (1991). Liberal arts, experiential learning and public service: Necessary ingredients for socially responsible undergraduate education. Journal of Cooperative Education 27:55-68.

Terosky, A. L. (2005). Taking teaching seriously: A study of university professors and their undergraduate teaching. Teachers College, NY: Columbia University.

Terosky, A. L., O’Meara, K. \& Campbell C. M. (2014).Enabling possibility: Women associate professors' sense of agency in career advancement.Journal of Diversity in Higher Education 7 (1), 58-76.

Tooby, J. \&Cosmides, L. (1996). Friendship and the banker's paradox: Other pathways to the evolution of adaptations for altruism.Proceedings of the British Academy 88

Vogelgesang, L. J., Denson, N. \&Jayakumar, U. M. (2010). What determines faculty-engaged scholarship.The Review of Higher Education, 33(4), 437-472.

Weerts, D., \&Sandmann, L. (2010).Community engagement and boundary-spanning roles at research universities.The Journal of Higher Education, 702-727.

Widjaja E (2010). Motivation Behind Volunteerism. CMC Senior Theses Retrieved April, 2012, from http://scholarship.claremont.edu/cmc_theses/4

Ziker, J. (2014). The Long, Lonely Job of Homo Academicus. The Blue Review. 